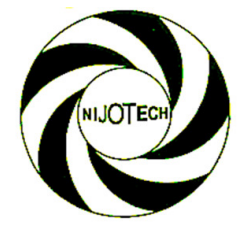

Nigerian Journal of Technology (NIJOTECH)

Vol. 35, No. 1, January 2016, pp. 107 - 113

Copyright@ Faculty of Engineering, University of Nigeria, Nsukka,

Print ISSN: 0331-8443, Electronic ISSN: 2467-8821

www.nijotech.com

http://dx.doi.org/10.4314/njt.v35i1.17

\title{
ANALYSIS OF COCONUT ETHYL ESTER (BIODIESEL) AND FOSSIL DIESEL BLENDING: PROPERTIES AND CORROSION CHARACTERISTICS
}

\author{
O. D. Samuel ${ }^{1,}{ }^{*}$, F. I. Ashiedu ${ }^{2}$ and B. U. Oreko ${ }^{3}$ \\ 1, 2,3Department of Mechanical Engineering, Federal University of Petroleum Resources, EFFurun, Nigeria \\ E-mail addresses: ${ }^{1}$ samuel.david@fupre.edu.ng, ${ }^{2}$ ashiedu.ifeanyi@fupre.edu.ng, ${ }^{3}$ oreko.benjamin@fupre.edu.ng
}

\begin{abstract}
The effect of biodiesel and its blends synthesized from coconut oil (CNO) via alkali catalyzed transeterification on the key fuel properties and corrosion characteristics of copper were investigated. The transesterification of the CNO via ethanol in the presence of potassium hydroxide was performed and the resulting coconut oil ethyl ester (COEE) was blended with fossil diesel (BO). The fuel properties such as density, kinematic viscosity (KV), pour and cloud points (PP and CP, respectively) and American Petroleum Institute of Gravity (API) of BO, COEE-diesel blend (B50) and COEE (B100) were characterized and compared with that of ASTM D6751 and EN14214 standards. Static immersion tests were conducted by exposing copper coupons toBO, B50 and B100 at different temperatures (50, 65 and $80^{\circ} \mathrm{C}$ ) for 5 days. Corrosion rates of copper in these fuels were determined by weight loss method. Also, during the period of investigation, these fuels were analyzed by measuring total acid number (TAN). The results showed that the density, KV, PP and CPincreased while the API gravity decreased as the percentage of the biodiesel in the blend increased. The highest corrosion rates for copper at the end of the investigation were $0.054,0.0954$ and 0.139 mpy in BO, B5O and B100, respectively. The minimum TAN (0.17 mg KOH/g) and maximum TAN (0.62 mg KOH/g) were observed in $B O$ and $B 100$ containing copper, respectively.
\end{abstract}

Keywords: Biodiesel, Viscosity, Coconut oil, Corrosion, Fossil fuel, Total Acid Number.

\section{INTRODUCTION}

Energy is an indispensable and significant issue of world concern. Major energy supply is produced from fossil sources of petroleum, coal and gas [1]. The huge energy demand in the industrialized world and the pollution problems caused by the widespread use of fossil fuels has made it increasingly necessary to develop alternative sources of energy to resolve the problems associated with fossil fuel [2,3]. Biodiesel fuels are gaining global interest as a substitute or blend component for fossil diesel. Biodiesel is synthesized from the reaction of vegetable oils or animal fats and methanol or ethanol with catalysts. Nwakaire and Durugu [4] hinted that viscosity of oil is reduced after transesterification and the biodiesel produced will be prevented from clogging the nozzles of the injector. The technical advantages associated with biodiesel over conventional diesel are super high flash point, biodegradable, inherent lubricity high cetane number, and reduced exhaust emission [5].

Despite the afore-mentioned technical advantages of the biodiesel over fossil diesel, corrosion in biodiesel has been reported to be severe than that of fossil diesel [6]. Kaul, et al [7] investigated the corrosion behaviour of biodiesels synthesised from seed oils from different regions in India. Their reports indicated that Salvadora biodiesel showed marked corrosion on both metal parts of diesel engine whereas biodiesel from other oils showed less corrosion effect as compared to fossil diesel. Chew, et al [8] compared corrosion of aluminium and magnesium in palm biodiesel. They reported that magnesium surface showed yellowish-like sticky mass while alumiunm remained unchanged. Norouzi, et al [9] investigated effect of rapeseed oil biodiesel blends on aluminium and copper. They reported that copper was susceptible to corrosion than copper. Galler, et al [10] hinted that brass and copper are subjected to corrosion than steel. The authors remarked that carbon content in the steel could be a tendency for its high resistance to corrosion. Sylvester, et al [11] reported the rate of corrosion of zinc and copper from biodiesel derived from olive, ground nut and soya oils. The authors concluded that copper materials have a 
higher corrosion rate in the biodiesel compared to zinc material. They further reported that corrosion rate of zinc materials increased with an increase in temperature of the biodiesel over a period of time. Jakeria et al [12] Investigated effect of two organic corrosion inhibitors (benzotriazole and adenine) on the corrosiveness of palm biodiesel. Their results indicated that mild steel surface degenerated less than that of copper surface in palm biodiesel without corrosion inhibitors. They further remarked that benzotriazole was more effective in corrosion inhibition of copper and mild steel than that of adenine in the palm biodiesel. However, there was no study reported on the blend characterization and corrosion of copper exposed to coconut biodiesel. The present study targets to investigate the fuel property of coconut oil ethyl ester (COEE) and its blends. The study further wants to investigate the effect of the blend concentration and temperature on the copper exposed to COEE-diesel fuel blends.

\section{EXPERIMENTAL}

\subsection{Materials and Methods}

Coconut oil ethyl ester (COEE) was produced by transesterfying coconut oil with ethanol in the presence of potassium hydroxide $(\mathrm{KOH})$ catalyst. The fossil diesel (B0) was procured from Nigerian National Petroleum Corporation filling station, Abeokuta, Nigeria. The physico-chemical properties of synthesized COEE and B0 are presented in Table 1. The data for B0 and COEE in Table 1 were measured in the Light House, Warri, Delta State, Nigeria. The density was measured with hydrometer according to the ASTM D1298 standard method of testing.The kinematic viscosity $\left(\mathrm{mm} / \mathrm{s}^{2}\right)$ was measured with a Gallenkamp viscometer at $40{ }^{\circ} \mathrm{C}$ according to the ASTM D445. The sample flash point was determined with a flash point tester (Setaflash series)by following the ASTM D56 procedure. The cloud and pour points were determined with a pour and cloud point analyzer following the ASTM D97 procedure. The acid value (AV, mg KOH/g) of the COEE-diesel blends was determined following AOCS standard test method [13].

\subsection{Corrosion Experiments and its Analysis}

The test coupons of pure copper (99.98\%) of $25 \mathrm{~mm} \mathrm{x}$ $25 \mathrm{~mm} \times 1 \mathrm{~mm}$ were prepared from square sheet plate by machining and grinding. To hang the coupons into fuels, a hole of $1 \mathrm{~mm}$ diameter was drilled near the edge of the specimen. Prior to immersion, the coupon was thoroughly cleaned with acetone and distilled water. Afterwards, these were immersed in 10\% $\mathrm{H}_{2} \mathrm{SO}_{4}$ at room temperature for few minutes followed by washing in distilled water. Acetone was employed to degrease all the samples.

During the immersion time, the coupons were immersed into biodiesel and its blends and the tempearature of the water batch containing the fuel types (B0, B50 and B100) was separately maintained at tempearture of 50,65 and $80^{\circ} \mathrm{C}$ in 5 days. Digital weighing balance was used to measure the weight of the coupon before and after exposure the coupon to different fuels. The corrosion test analyses were investigated using equation (1) $[14,15,16]$.

$$
\text { Corrosion rate }(m p y)=\frac{534 W}{D A T}
$$

Here corrosion rate "mpy" stands for mils (0.001 inch) per year; $w$ is the weight loss ( $g$ ) D is the Density of metal $\left(\mathrm{g} / \mathrm{m}^{3}\right)$; A is the Area of the metals exposed $\left(\mathrm{m}^{2}\right)$; T is the Exposed Time (hr) and C is the Constant term $=534$.

Furthermore, degredation of the fuel types were assessed using total acid number (TAN). A high speeddigital camera was employed to further investigate the surface of the copper, adopting the method earlier reported [14].

\section{RESULTS AND DİSCUSSION}

\subsection{Characterization of Biodiesel}

Fuel properties of biodiesel synthesised from Nigerian coconut oil are presented in Table 1 . The oil had a fatty acid composition as follows: caprolic acid $0.2 \%$, caprylic $4.8 \%$, capric acid $4.8 \%$, lauric acid $54.5 \%$, myristic acid $18.8 \%$, palmitic acid $8.3 \%$, strearic acid $2.8 \%$, oleic acid $5.0 \%$, and linoleic acid $0.8 \%$ (by weight).The densities of coconut oil ethyl ester (COEE) $\left(884 \mathrm{~kg} / \mathrm{m}^{3}\right)$ is within the range of EN 14214 $\left(860-900 \mathrm{~kg} / \mathrm{m}^{3}\right)$ and compared favourably with the density of tobacco seed oil methyl ester (TSOME) (890 $\mathrm{kg} / \mathrm{m}^{3}$ ) and has the same value with that of melon seed oil methyl ester (MSOME) $\left(884 \mathrm{~kg} / \mathrm{m}^{3}\right)$ but higher than that of the fossil diesel $\left(855 \mathrm{~kg} / \mathrm{m}^{3}\right)$. Valente et al. [17] attested that the engine fuel injection has to be optimized to account for the higher biodiesel density in comparison to the conventional diesel. Owner and Coley [18] further remarked that fuel of higher density produce more brake power and soot emission from unmodified diesel engine. As can be noticed in Fig. 1, density increased as the perecentage of COEE increased in the blend. The

Vol. 35, No 1, January $2016 \quad 108$ 
density of the blend of COEE appears to be curvelinear with the highest regression $\left(\mathrm{R}^{2}=1\right)$ in equation (2):

$$
D=-2.5 x^{2}+24.5 x+833
$$

where $\mathrm{x}$ is the volume fraction of COEE

The American Petroleum Institue of Gravity (API gravity) of the COEE was determined to be 34.0 while that of the fossil diesel, and B50 determined as 30.57 and 28.57, respectively. As potrayed in Fig. 2, the API gravity decreased as the percentage of the COEE increased in the blend. This is in consistence with the obervation reported for the karanja oil biodiesel and its blends [19].

The kinematic viscosity (KV) of COEE (4.629 $\mathrm{mm}^{2} / \mathrm{s}$ ) certified the ASTM D6751 and EN 14214 standards. The KV of COEE is relatively higher than those of MSOME (3.91 $\left.\mathrm{mm}^{2} / \mathrm{s}\right)$ reported by [20] and [21], respectively. High fuel viscosity has been reported to affect proper combustion and fuel atomization [18]. As can be observed in Fig. 3, viscosity increased as the percentage of COEE increased in the blend and the KV of the blend of COEE appears to be curvelinear with the highest regression $\left(\mathrm{R}^{2}=1\right)$ in equation 3 :

$$
K V=0.015 x^{2}+0.866 x+1.92
$$

where $\mathrm{x}$ is the volume fraction of COEE. The flash point (FP) determined for COEE was $160{ }^{\circ} \mathrm{C}$ and it certified the ASTM D6751 and EN 14214 standard specifications. The flash point of COEE is higher than that of MSOME $\left(142^{\circ} \mathrm{C}\right)$ and TSOME $\left(126^{\circ} \mathrm{C}\right)[20,21]$. The high FP of COEE $\left(160^{\circ} \mathrm{C}\right)$ implies that the fuel can be stored for further atomotive application. As can be observed in Fig. 4, the FP increased as the concentration of the COEE increased in the blend and the relationship between the FP and the biodiesel fraction ( $\mathrm{x}$ ) is curvelinear as given in the equation (4).

$$
F P=-18 x^{2}+118 x-32
$$

The pour and cloud points of COEE were determined to be -13 and $-3{ }^{\circ} \mathrm{C}$, respectively. For all the blends, the pour and cloud points increased as the percentage of COEE increased. Depicted in Figs. 5 and 6 are the respective pour and cloud points with the volume fraction of COEE (x) in the blend and the curves seem to be linear for both pour and cloud points.

The acid value (AV) (0.31 mg KOH/g) determined for COEE is in accordance with the acidity specification standards ( $\leq 0.50 \mathrm{mg} \mathrm{KOH} / \mathrm{g}$ ) though higher than that of MSOME $(0.11 \mathrm{mg} \mathrm{KOH} / \mathrm{g})$ and lower than that of TSOME (0.420). Fig. 7 shows that the AV follow a second-degree curved with the biodiesel fraction as represented in equation (5)

$$
A V=0.025 x^{2}+0.025 x+0.07
$$

\begin{tabular}{|c|c|c|c|c|c|c|c|}
\hline Property & Unit & $\mathrm{COEE}^{\mathrm{a}}$ & $\begin{array}{c}\text { ASTM } \\
\text { Standard } \\
\text { D6751-02 } \\
\end{array}$ & $\begin{array}{c}\text { EU } \\
\text { Standard } \\
\text { EN14214 } \\
\end{array}$ & MSOME $^{\mathrm{b}}$ & TSOMEc & $\begin{array}{c}\text { Fossil Diesel } \\
\text { Fuel } \\
\text { B0 } \\
\end{array}$ \\
\hline Density, $15^{\circ} \mathrm{C}$ & $\mathrm{kg} / \mathrm{m}^{3}$ & 884 & NS & $860-900$ & 884 & 890 & 855 \\
\hline API gravity & - & & NS & NS & - & - & \\
\hline $\begin{array}{l}\text { Kinematic } \\
\text { viscosity; } 40{ }^{\circ} \mathrm{C}\end{array}$ & $\mathrm{mm}^{2} / \mathrm{s}$ & 4.629 & $1.9-6.0$ & $3.5-5.0$ & 3.91 & 3.87 & 2.802 \\
\hline Flash point & ${ }^{\circ} \mathrm{C}$ & 160 & $130 \mathrm{~min}$ & $120 \mathrm{~min}$ & 142 & 126 & 68 \\
\hline Pour Point & ${ }^{\circ} \mathrm{C}$ & -13 & $<0$ & $<0$ & - & - & -18 \\
\hline Cloud Point & ${ }^{\circ} \mathrm{C}$ & -3 & Report & - & 0.5 & - & -12 \\
\hline Acid value & $\begin{array}{c}\mathrm{mg} \\
\mathrm{KOH} / \mathrm{g}\end{array}$ & 0.31 & $0.5 \max$ & $0.50 \max$ & 0.11 & 0.420 & 0.12 \\
\hline
\end{tabular}

Table 1:Characterization of Coconut Oil Ethyl Ester in comparison with ASTM and EU standard, and esters from oil seeds and fossil diesel

a[This work $] ;{ }^{b}[20] ;{ }^{c}[21]$ 


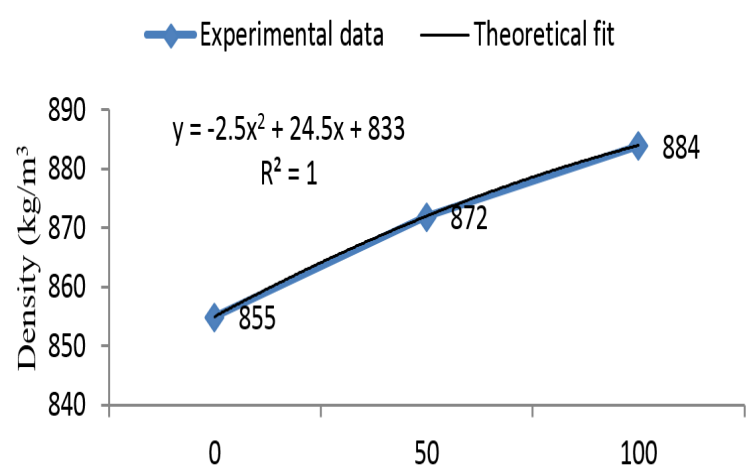

Figure 1: Variation of Density with Biodiesel Fraction

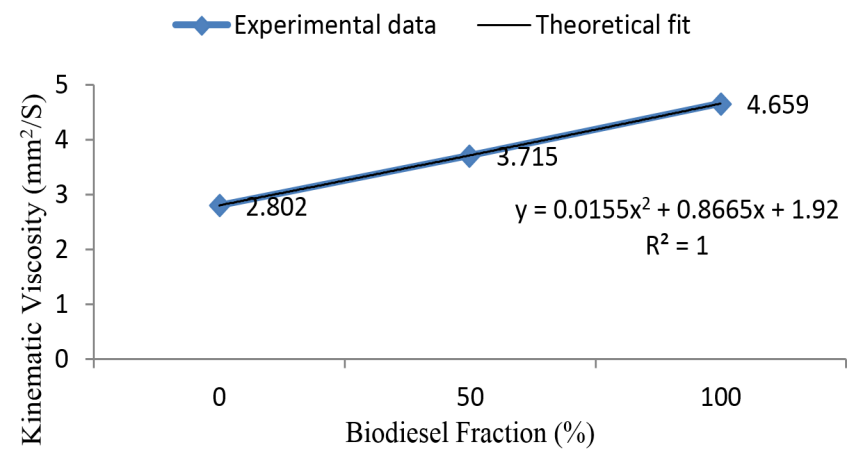

Figure 3: Variation of Kinematic Viscosity with Biodiesel Fraction

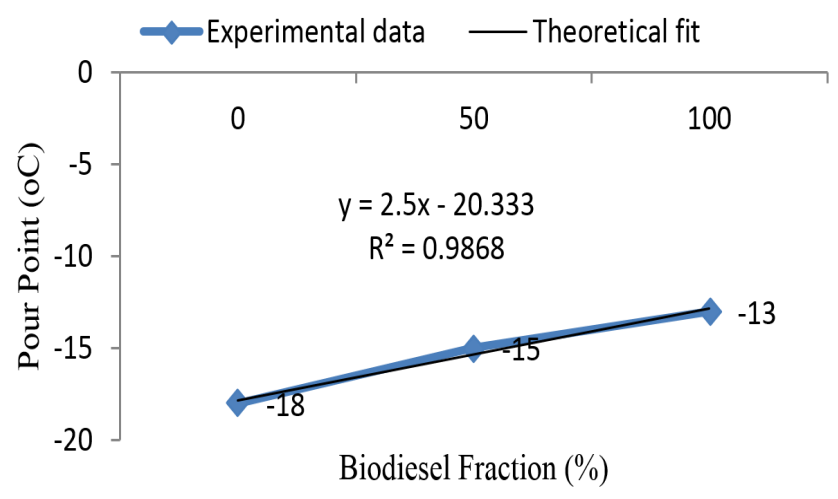

Figure 5: Variation of Pour Point with Biodiesel Fraction

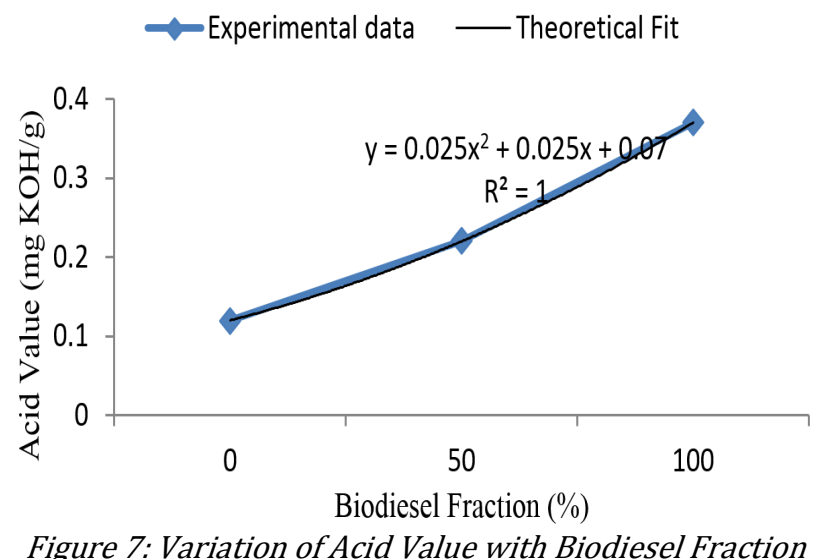

Figure 7: Variation of Acid Value with Biodiesel Fraction

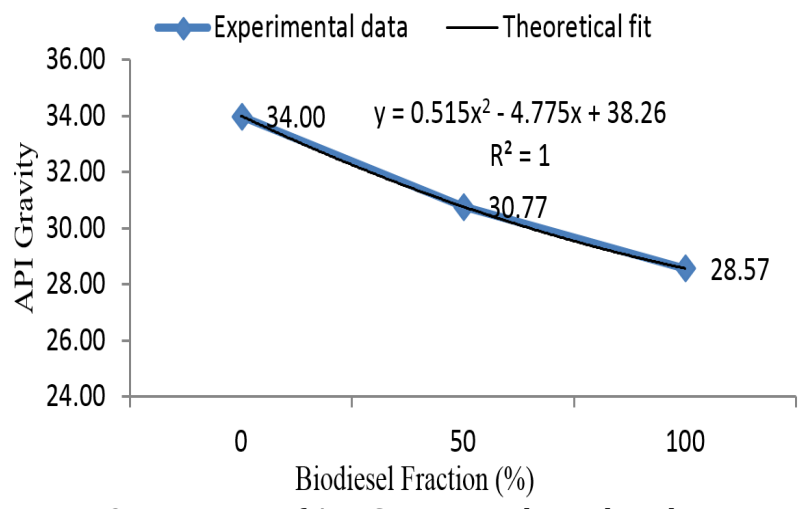

Figure 2: Variation of API Gravity with Biodiesel Fraction

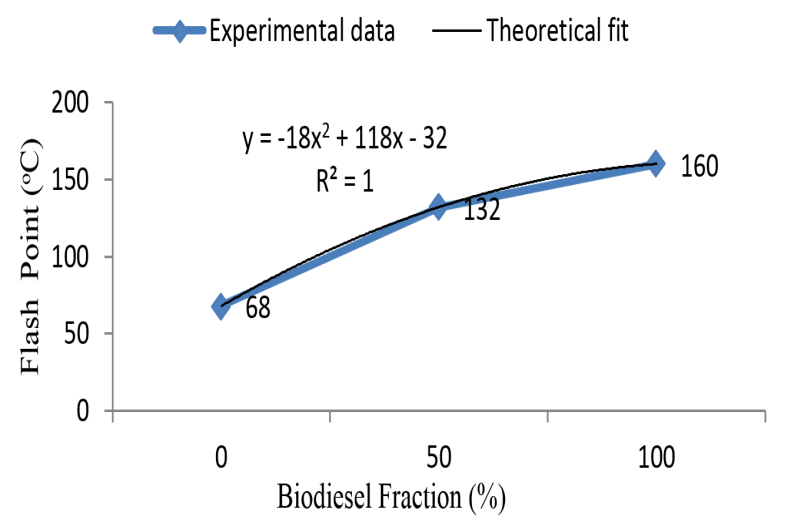

Figure 4: Variation of Flash Point with Biodiesel Fraction

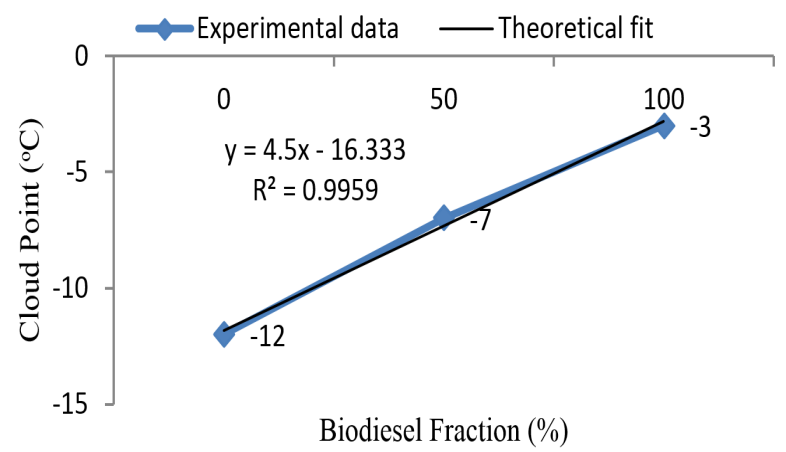

Figure 6: Variation of Cloud Point with Biodiesel Fraction

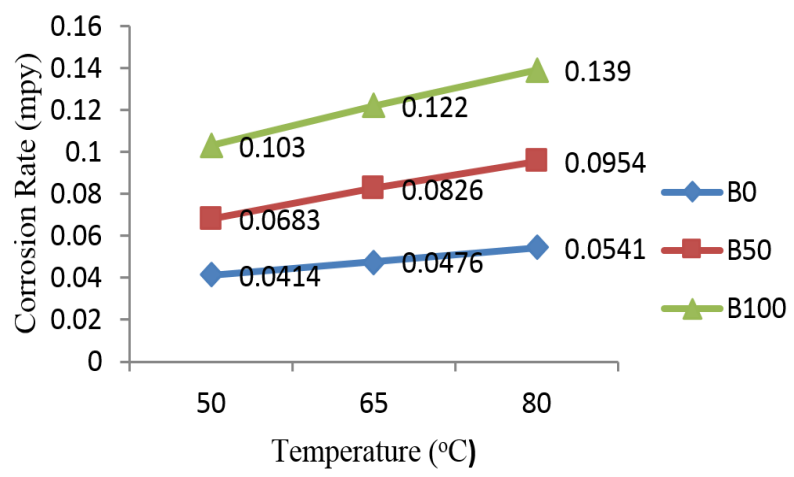

Figure 8: Variation of Copper Corrosion Rates in Coconut Biodiesel and Diesel 


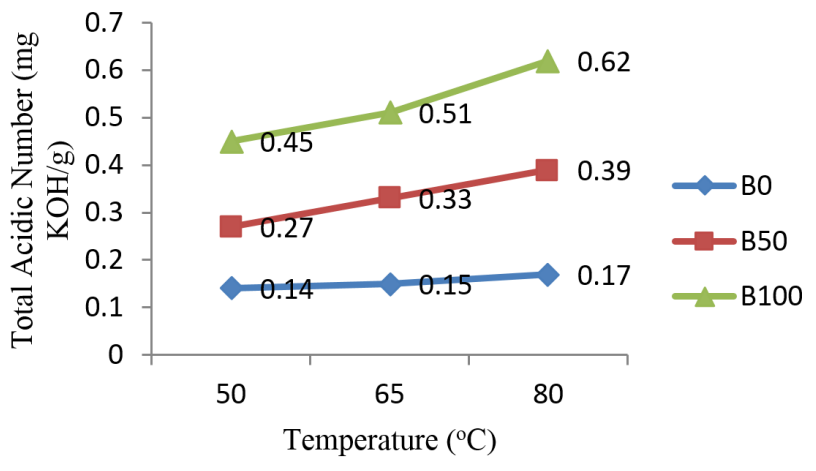

Figure 9: Variation of Total Acidic Number with Biodiesel Concentration

\subsection{Corrosion Rate}

The variant corrosion characteristics and the impacts on copper exposed to coconut oil ethyl ester-diesel blend were evaluated by calculating their corrosion rates, as depicted in Fig. 8.

The corrosiveness of coconut oil ethyl ester (COEE) on copper was more severe than those of COEE blend (B50) and unblended diesel (B0): The corrosion rate ranged from 0.103 to 0.139 mils/year for COEE, 0.0683 to 0.0954 miles/year for B50 and 0.0414 to 0.054 mils/year in B0. As can be observed in Fig. 8, the corrosion rate of copper in COEE was approximately
3 times faster than in diesel, and it is 2 times faster in B50 than that in the fossil diesel. The higher corrosion rate of metals exposed to biodiesel compared to conventional diesel has been attributed to the oxidation of component in biodiesel leading to the formation of metallic oxides [22, 23]. However, the lower corrosion rate on metals in diesel was linked to chemical stability of the conventional diesel.

As depicted in Fig. 9, the total acid number (TAN) values of COEE are higher than those of B50 and B0. The increased TAN has been reported to be associated with the oxidation of biodiesel [5].

\subsection{Corrosion Morphologies}

The corrosion morphologies and mechanism of copper surface were analyzed using digital pictures in order to further reveal the effect of fuel types on the corrosion behaviour of copper. Presented in Table 2 are the pictures of the copper surface before and after exposed to coconut biodiesel-diesel blend. The corrosion rendered some evidence changes in the morhologies of copper surface, except for the copper exposed to fossil diesel, where minor changes occured in reaction with the conventional diesel.

Table 2. Pictures of copper surace before and after immersed in BO, B5O and B100.

$\mathrm{B} 100$ at $50^{\circ} \mathrm{C}$

$\mathrm{B} 100$ at $65^{\circ} \mathrm{C}$

B100 at $80^{\circ} \mathrm{C}$
Before Immersion

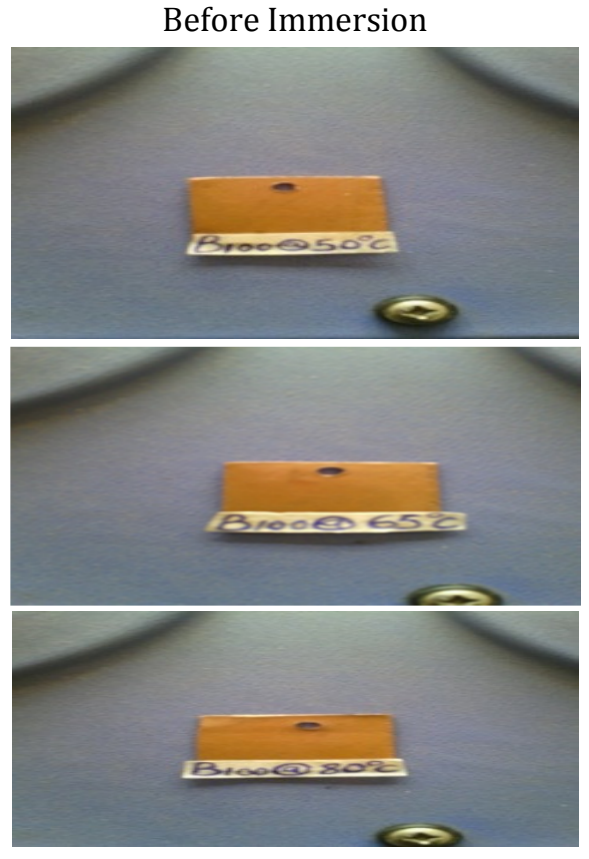

After Immersion

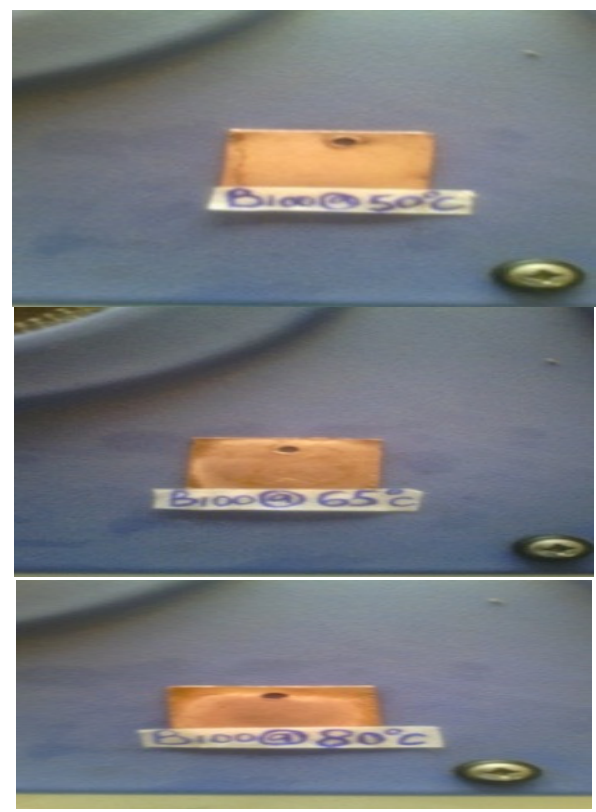



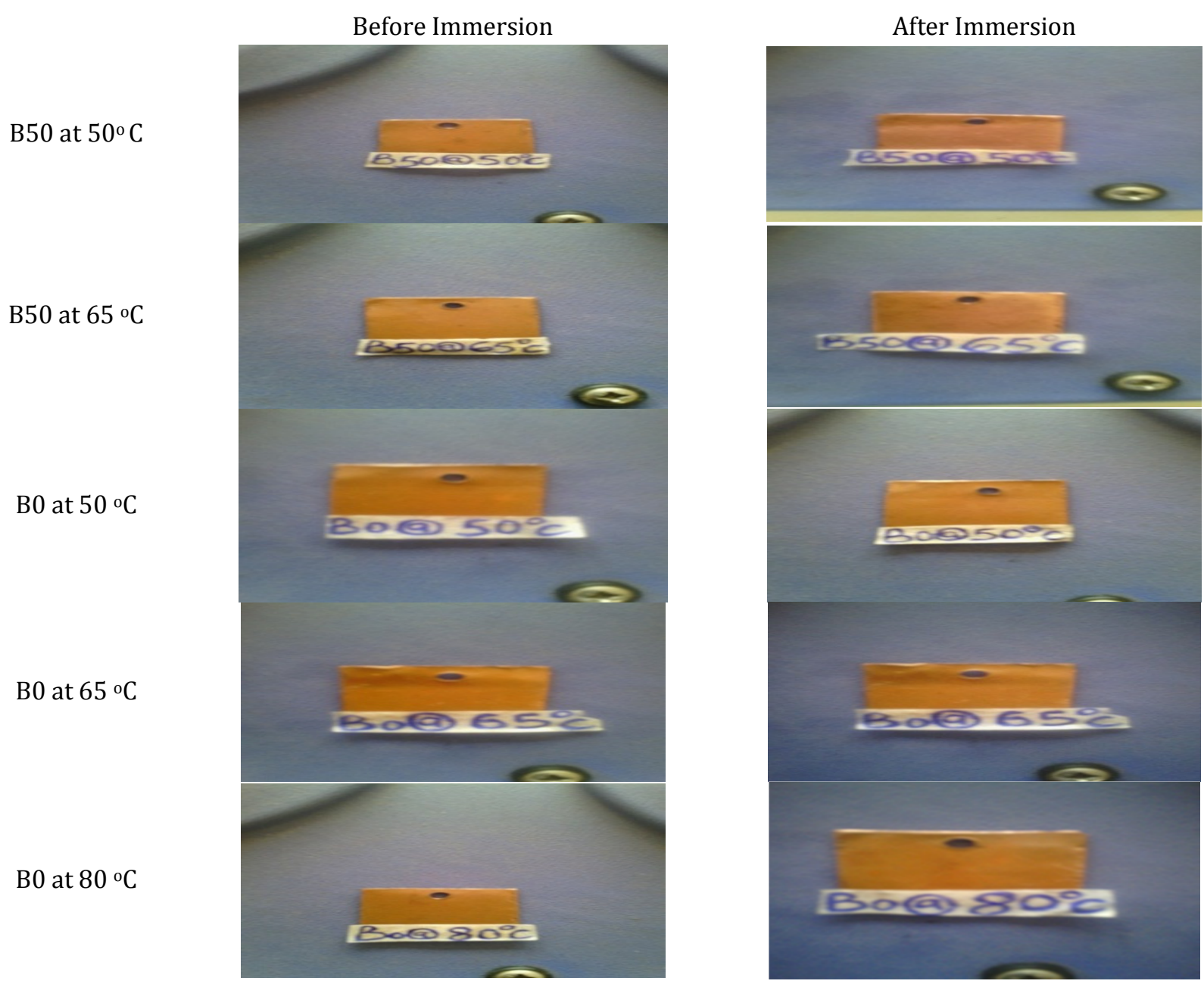

\section{CONCLUSION}

Based on the experimental study and results, the following explanation can be deduced:

- Data for the fuel properties of coconut biodieselfossil diesel blends has been found to meet the ASTM and EU standard specifications.

- The densities, kinematic viscosity, flash point, pour and cloud points increased while the API gravity decreased as the percentage of coconut oil ethyl ester increased in the blends.

- Copper exposed to the biodiesel and biodiesel-diesel blend (B50) are more susceptible to corrosion and degradation, as evident by increased corrosion rate and total acid number, respectively.

\section{REFERENCES}

[1] Da Silva, N.D.L., Garnica, J.A., Batistella, C.B., Maiciel, M.R.W. and Filho, R.M. "Use of experimental design to investigate biodiesel production by multiple-stage ultra- shear reactor" Bioresouce Technology Vol.102, Febuary 2011, Issue 3, pp. 2672-2677.
[2] Srivastava, A. and Prasad, R. "Triglyceride- based diesel fuels", Renewable and Sustainable Energy Reviews, Vol. 4, June 2000, Issue 2, pp. 111-133.

[3] Momoh, O.R., Audu, H.I. and Binta, Z.B., "Investigating the production of biodiesel from alphonso mango seed oil", Nigerian Journal of Technology, Vol. 33, October, 2014, No.4,pp. 497-503.

[4] Nwakare, J.N. and Durugu, S., "Determination of physico-chemical properties of oleander seed oil for biodiesel production", Nigerian Journal of Technology, Vol. 32, November 2013, No. 3, pp. 440442.

[5] Moser, B.R. "Biodiesel production, properties, and feedstock", In Biofuels. Springer New York, 2011, pp. 285-347.

[6] Fazal, M.A., Haseeb, A.S.M.A. and Masjuki, H.H. "Degredation of automotive materials in palm biodiesel", Energy, Vol. 40, April 2012, Issue 1, pp. 76-83.

[7] Kaul, S., Saxena, R.C., Kumar, A., Negi, M.S., Bhatnagar, A.K., "Corrosion behaviour of biodiesel from seed oils of India origin on diesel engine parts", Fuel Processing Technology, Vol. 88, March 2000, Issue 3, pp. 303-307. 
[8] Chew, K.V., Haseeb, A.S.M.A., Masjuki, H.H., Fazal, M.A. and Gupta, M. "Corrosion of magnesium in palm biodiesel: A comparative evaluation”, Energy, Vol. 57, August 2013, pp. 478 - 483.

[9] Norouzi, S., Eslami, F., Wyszynski, M.L. and Tsolakis, A."Corrosion effects of RME in blends with ULSD on aluminium and copper",Fuel Processing technology, Vol. 104, December 2012, pp. $204-210$.

[10] Gellar, D.P., Adams, T.T., Goodrum, J.W. and Pendergress, J. "Storage stabilityof poultry fat and diesel fuel mixtures: Specfic gravity and viscosity", Fuel, Vol. 87, January 2008, Issue 1, pp. 92-102.

[11] Sylvester, O., Adams, F.V. andOkoro, L.N., "Impact of biodiesel on the corrosion of zinc and copper strips", International Journal of Scientific and Engineering Research, Vol. 6, Febuary 2015, Issue 2, pp. 546- 549.

[12] Jakeria, M.R., Fazal, M.A. and Haseeb, A.S.M.A. "Effect of corrosion inhibitors on corrosiveness of palm biodiesel", Corrosion Engineering, Science and Technology, Vol. 50, 2015, No. 1, pp. $56-62$.

[13] Official methods and recommended practices of the American Oil Chemists Society. Champaign, IL, AOCS press, 1998.

[14] Fernando, S., Karra, P., Hernandez, R. and Jha, S.K. "Effect of incompletely converted soybean oil on biodiesel quality”, Energy, Vol. 32, May 2007, Issue 5, pp. 844-851.

[15] Jakab, M.A., Westbrook, S.R. and Hutzler, S.A. "Testing for compatibility of steel with biodiesel", Project No. 08.13070, Southwest Research Institute, April 2008.

[16] Zongjie, H., Zhou, Y., Deng, J., Wu, Z. and Li, L. "Compatibility of biodiesels and their blends with typical rubbers and copperish metals", Society of Automotive Engineers Technical Paper, 2010-010476, 2010.

[17] Valente, O.S., Pasa, V.M.D.,Belchor, C.R.P. and Sodre, J.R. "Physical-chemical properties of waste cooking oil biodiesel and castor oil biodiesel blend", Fuel, Vol. 90, April 2011, pp.1700-1702.

[18] Owen, K. and Coley, T. "Automotive fuels reference book", 2nd ed. USA, 1995.

[19] Data, A. "Optimization engine performance and emission characteristics on variable compression ratio diesel engine fuelled with karanja oil methyl ester using taguchi method and grey relational analysis", Ph.d dissertation, Jadavpur University Kolkata, 2010.

[20] Giwa, S.O.,Chuah, L. A. And Adam, N.M. "Fuel properties and rheological behaviour of biodiesel from egusi (Colocynthis citrullus L.) seed kernel", Fuel Processing Technology, Vol. 122, June 2014, pp. $42-48$.

[21] Waheed, M.A., Samuel, O.D., Bolaji, B.O. and Dairo, O.U. " RSM based optimization of biodiesel production from tobacco seed oil" In: Renewable energy and Sustainable Development, 5:85-101, 2015.

[22] Haseeb, A.S.M.A., H.H. Masjuki, H.H., Ann, L.J. and Fazal, M.A."Corrosion characteristics of copper and leaded bronze in palm biodiesel", Fuel Processing Technology, Vol. 91, March 2010, Issue 3, pp. 329334.

[23] Liu, J. and Fang, Y.K. "Effect of dissolved oxygen on the corrosion of 20R steel in biodiesel", reactor raw mixture", Cororrosion and Protection , 10, 2009, pp. 711-713. 